\title{
UITDAGINGS VIR DIE NED GEREF KERK IN SUIDELIKE AFRIKA MET MALAWI EN ZAMBIë AS ILLUSTRASIEGEBIEDE
}

D CRAFFORD

\begin{abstract}
CHALLENGES FOR THE DUTCH REFORMED CHURCH IN SOUTHERN AFRICA WITH MALAWI AND ZAMBIA AS ILLUSTRATION AREAS

What will be the challenges for the Dutch Reformed Church in South Africa if in the coming decades its isolation from Africa could be ended because of political developments in a post-apartheid era? The Dutch Reformed Church planted indigenous churches in many African Countries like Botswana, Malawi, Zimbabwe, Zambia, Mozambique and Namibia. The role of the church in Africa will be determined by its relations with these younger churches. The challenges in the fields of evangelism. church ministry, the youth and in the socioeconomic and political areas are illustrated specifically in the cases of Malawi and Zambia.
\end{abstract}

Sal Suid-Afrika in die komende dekade sy politieke isolasie in suidelike Afrika deurbreek? Daar is heenwysers in die rigting. Indien dit gebeur, sal daar onverwagte deure oopgaan vir die Ned Geref Kerk. Dit kan die kerk voor een van die grootste uitdagings van sy bestaan plaas, naamlik om uit ' $n$ era van isolasie te breek en ' $n$ konstruktiewe rol te speel in die ontwikkeling en kerstening van suidelike Afrika in 'n post-koloniale en 'n postapartheid tydvak.

Sal dit nie 'n wonderwerk wees indien die "apartheidskerk" van weleer weer algemeen aanvaar kan word as ' $n$ instrument van diensbaarheid aan suidelike Afrika nie! Dit sou die ware sin van dié kerk se bestaan in Afrika illustreer en aan sy lidmate geleentheid bied om diens te lewer aan 'n kontinent met vele geestelike en sosio-ekonomiese probleme.

Die veranderinge op politieke gebied maak dit moontlik vir die kerk om drome van konstruktiewe betrokkenheid te droom. Die Nkomati-verdrag wat Suid-Afrika se destabiliserende rol in Mosambiek omgekeer het in 'n stabiliserende rol het die veranderende verhoudinge in suidelike Afrika ingelui. Die proses is versterk met die konsensus wat bereik is vir die implementering van Resolusie 435 in Namibië en die suksesvolle verkiesings wat die land onherroeplik op die pad van onafhanklikheid geplaas het. Die onttrekking van Kubaanse en Suid-Afrikaanse soldate aan Angola het die 
moontlikheid geskep vir meer ontspanne verhoudinge tussen Suid-Afrika en Angola. Die direkte gevolge van die ontwikkelinge was gesprekke van president F W de Klerk met leiers van Mosambiek, Zambië, Zaire en Ivoorkus.

Die swak skakel in meer ontspanne politieke verhoudinge in suidelike Afrika is Zimbabwe waar die Marxistiese regering van mnr Mugabe afwysend bly teenoor samewerking met Suid-Afrika. ' $n$ Verdere probleem in die verband is natuurlik Suid-Afrika self. Voordat politieke oplossings in SuidAfrika self nie gevind word nie, sal die deure na Afrika maar slegs op 'n skrefie oop bly.

Die doel van hierdie artikel is egter nie om oor politieke ontwikkelinge te bespiegel nie, maar om die lig te laat val op kerklike betrokkenheid en verhoudinge in suidelike Afrika. Daar is egter sterk aanduidings dat in die dekade wat kom, heelwat meer lande as net Malawi betrokkenheid van Suid-Afrikaners sal verwelkom. Indien dit gebeur, sal die Ned Geref Kerk gereed moet wees om agressief met sy getuienis en diens by die oop deure in te beweeg.

'n Belangrike voorwaarde waaraan dié kerk sal moet voldoen, is om die spanninge op te los wat daar bestaan binne die familie van Ned Geref Kerke. Dit is tog absurd om te dink dat die Ned Geref Kerk vir Afrika iets kan beteken as hy nie eens in staat is om vrede, samewerking en eenheid in eie geledere te bewerkstellig nie. As daar egter harmonie tussen wit en swart in die kerk bestaan, kan daar met nuwe entoesiasme uitbeweeg word om die uitdagings wat Afrika bied te beantwoord.

Die probleem van kerklike verhoudinge en kerklike eenheid binne die RSA is egter 'n tema van so ' $n$ omvang dat dit nie hier die plek is om daaroor uit te wei nie. Ons wil die lig nou laat val op die Ned Geref Kerk se verhoudinge met susterkerke in onafhanklike buurstate met die klem op Malawi en Zambië waar die mees lewenskragtige Gereformeerde Kerk uit die Ned Geref Familie te vinde is.

\section{DIE N G KERK EN SY SUSTERSKERKE IN SUIDELIKE AFRIKA}

Die Ned Geref Kerk is in die gelukkige posisie dat in byna al ons buurstate daar lewenskragtige Gereformeerde Kerke is wat uit sy sendingwerk gebore is. Hierdie kerke het almal reeds 'n besondere mate van selfstandigheid ontwikkel en speel 'n betekenisvolle rol in die lewe van hulle onderskeie lande. Die Ned Geref Kerk se uitdaging is dus nie meer in die eerste plek kerkplanting nie, maar juis om hulp en steun te verleen aan die geplante kerke om die geestelike, morele, sosio-ekonomiese en politieke vraagstukke van hulle eie lande te help oplos en om die oorblywende 
kersteningstaak voort te sit. Terselfdertyd kan hierdie susterskerke in ons buurstate ook die Ned Geref Kerk help om tot broederlike samewerking met swart kerke en gemeenskappe te kom in die nuwe era waarheen ons nou beweeg.

\section{Botswana}

Die oudste sendingwerk van die Ned Geref Kerk (Kaapland) in suidelike Afrika buite die grense van die huidige RSA het in Mei 1877 begin toe eerwaarde Pieter Brink vanaf Saulspoort hom by die Bakgatla-stam gaan voeg het wat na Mochudi verhuis het. In 1892 het hoofman Lentswe hom laat doop en so sy stam onder die invloedsfeer van die kerk gebring. As vrug op die sendingwerk is gemeentes gebore wat eers by die NGKA van Transvaal ingeskakel was. Na die onafhanklikheidswording van Botswana was daar 'n groeiende behoefte aan 'n selfstandige kerk in die gebied. Op 20 November 1979 is die Dutch Reformed Church in Botswana gekonstitueer as 'n kerk waarby Swart-, Blanke- en Kleurlinggemeentes ingeskakel het. Dit is 'n kerk met sewe gemeentes en bykans 5000 lidmate wat deur ses predikante bedien word.

Die Ned Geref Kerk se Sinode van Noord-Kaapland het noue bande met die kerk in Botswana en gee saam met die susterskerk aandag aan die uitdagings wat die land aan die kerk bied. ${ }^{1}$ Die politieke rustigheid in Botswana en die vryheid van optrede wat aan kerke gegun word, skep ruim geleenthede vir betrokkenheid by gemeenskapsdiens en kerstening.

\section{Malawi}

In 1889 het die eerste twee pioniersendelinge vanuit Kaapland in Malawi aangekom. Vanaf 24 tot 27 Augustus 1989 is die eeufees van die Ned Geref Kerk se sending in Malawi gevier.

As resultaat van die 100 jaar se sendingwerk is 'n kerk geplant wat saam met die vrug van die Skotse sending een kerkverband gevorm het. Die gemeentes wat uit die Ned Geref sending gebore is, vorm die Nkhomasinode van die Kerk van Midde-Afrika Presbiteriaans. Hierdie sinode bestaan uit 94 gemeentes met 200,000 lidmate wat deur 90 inheemse leraars bedien word. Die inheemse leraars word deur die kerk self onderhou. Die Ned Geref Kerk van Wes-Kaapland onderhou 35 gestuurdes uit Suid-Afrika waaronder 3 geordendes, 'n aantal onderwysers, hospitaalpersoneel, geestelike werksters, 'n bouer, 'n tegnikus en 'n tesourier.'

\section{Zimbabwe}

In 1891 het A A Louw die Sendingstasie Morgenster in Mashonaland aangelê. Uit die sendingwerk wat nou byna 100 jaar oud is, is die Reformed 
Church in Zimbabwe gebore. Dit is 'n kerk met 33 gemeentes en ongeveer 20,000 lidmate wat deur 23 inheemse leraars bedien word. Die sinode van Wes-Kaapland onderhou nog 27 gestuurdes wat op verskillende terreine hulp verteen aan die $\mathrm{RCZ}^{3}$

Die uitdagings vir die kerk in Zimbabwe hang saam met die feit dat die kerk moet bestaan en oorleef in 'n land met ' $n$ Marxistiese owerheid wat ook die moederkerk en die regering in Suid-Afrika nie goedgesind is nie.

\section{Zambië}

In 1899 het die Sinode van die OVS die eerste sendelinge na Zambië gestuur. Hier is die Reformed Church in Zambia (RCZ) geplant wat veral na die onafhanklikheidswording van die land besondere lewenskragtigheid openbaar het. Toe die RCZ in 1966 die werksaamhede van die Vrystaatse Kerk oorgeneem het, was daar 27 gemeentes met ongeveer 23,000 lidmate. In 1983 was daar reeds 58 gemeentes. In die vyf jaar daarna was daar dramatiese groei toe 25 nuwe gemeentes gestig is. In 1988 het die kerk 83 gemeentes gehad met ongeveer 120,000 lidmate wat deur 82 inheemse predikante bedien is. Die Ned Geref Kerk se aandeel bestaan uit die onderhoud van vier dosente aan die Justo Mwale Theological College en een jeugleraar wat die kerk met jeugbediening help.

\section{Mosambiek}

Met slegs ongeveer $8 \%$ van sy 12.5 miljoen inwoners gekersten, is Mosambiek seker een van die grootste oorgeblewe sendingakkers in Afrika. Die Ned Geref Kerk van Transvaal het in 1908 met sendingwerk daar begin maar moes weens teenkanting van die Rooms-Katolieke Kerk en die Portugese owerhede in 1922 die werk staak. Die kerk het egter onder leiding van ouderlinge steeds gegroei sodat die 255 lidmate van 1922 tot bykans 20,000 aangegroei het in 1989 in Angonia en Milanje-provinsies. Vanaf 1972 is die lidmate in Angonia opnuut in gemeentes georganiseer en ook in die Suide is 'n gemeente gestig in Maputo.

In 1977 is die bestaande gemeentes vir 'n eerste sinode byeengeroep en is die Igreja Reformada em Mocambique georganiseer. Die kerk het tans 18 gemeentes waarvan 2 in die Suide geleë is, 6 in Angonia en 10 in Milanje provinsie.

As gevolg van die oorlogsontwrigting in die land, leef bykans twee derdes van die meer as 20,000 lidmate as vlugtelinge in Malawi en word daar deur vier leraars bedien. In die Suide word 'n doseerpos aan die Ricatla Teologiese skool beman saam met dosente van ander Protestantse Kerke.

Die werk in Mosambiek staan onder beheer van 'n gesamentlike sen- 
dingkommissie waaraan die sinodes van Wes-Kaapland en Transvaal meewerk asook die Transvaalse Sinodes van die Ned Geref Kerk in Afrika.

Die oorlogsgeteisterde en verskeurde Mosambiek waarvan die ekonomie feitlik in duie gestort het, bied ook weer sy eiesoortige uitdagings aan die kerk. $^{5}$

\section{Namibië}

Die Ned Geref Kerk in Suidwes-Afrika het eers in 1955 in alle erns met sendingwerk begin. In 1975 kon as vrug op die sendingwerk die Sinode van die Evangeliese Gereformeerde Kerk in Afrika (EGKA) gevorm word. In dieselfde jaar is ook die Reformed Church in Caprivi met een gemeente, Ngweze, gestig.

By die sinode van 1987 het EGKA in ses streekskerke verdeel, naamlik EGKA-sentraal, EGKA-Kavango, EGKA-Oos, EGKA-Ovambo, EGKA-Ingreja Reformada (vlugtelinge uit Angola) en die Evangelical Reformed Church van die Caprivi.

EGKA het toe bestaan uit 27 gemeentes en 3 werkkringe met 3395 belydende lidmate en 3986 dooplidmate wat bedien is deur 25 leraars.

In al ses die bogenoemde buurstate van Suid-Afrika het die Christelike kerke te doen met besondere uitdagings wat eie is aan die besondere omstandighede van die land. Binne die opset van elke land het die kerke wat uit die Ned Geref Kerk se sending gebore is, weer sy eie uitdagings om 'n konstruktiewe rol te speel.

Ons wil vervolgens let op die besondere uitdagings wat daar bestaan vir die twee grootste en mees lewenskragtige jongkerke wat uit die Ned Geref Kerk se sending gebore is, naamlik die Nkhoma-sinode van die KMAP in Malawi en die RCZ in Zambië. Daar sal ook aandag gegee word aan die maniere waarop die Ned Geref Kerk kan help om die uitdagings te bowe te kom.

\section{UITDAGINGS VIR DIE KERK IN MALAWI}

Malawi met sy agt miljoen inwoners en 'n bevolkingsdigtheid van 84,7 per vierkante kilometer is een van die digbevolkste lande in Afrika. 6 Daarby het die land ' $n$ bevolkingsgroeikoers van meer as $3 \%$ per jaar wat die bevolking vroeg in die volgende eeu sal opstoot na meer as 12 miljoen.

Bykans $90 \%$ van die bevolking woon nog in tradisionele landelike dorpies. Daar is slegs drie stedelike gebiede, naamlik Blantyre, Lilongwe en Zomba. 
Vanweë beperkte industrialisasie is daar egter nie so 'n massale toestroming na die stede soos in Suid-Afrika en Zambië nie en Malawi het die haglike plakkerstoestande van ander groot stede in Afrika tot sover grootliks gespaar gebly. Verstedeiiking vind nietemin plaas teen $8 \%$ van die bevolking per jaar en sal 'n groeiende probleem word.

Malawi is ' $n$ arm land met 'n per capita inkomste van ongeveer 170 Amerikaanse dollar per jaar teenoor Suid-Afrika wat 'n per capita inkomste van ongeveer 850 dollar het. Tog is dit een van die min lande in Afrika wat sy inwoners self kan voed vanweë die groot klem wat op landbou gelê word. Armoede is ' $n$ relatiewe begrip. Met ' $n$ landboubevolking wat hulleself nog voed en besig hou op die grond, is Malawi 'n land van gelukkige mense met min hongersnood. Met ' $n$ inflasiekoers van $30 \%$ en dagloners wat dikwels minder as R1-00 per dag verdien, is daar nie veel moontlikheid om verbruikersgoedere te koop nie en moet mense met die basiese produkte van die grond af tevrede wees.

$\mathrm{Kane}^{7}$ het bereken dat Malawi se bevolking verdeel kan word in ongeveer 53\% Christene, $32 \%$ Tradisionaliste en $15 \%$ Moslems.

Die Bulletin van die United Bible Societies No 150/151, 1988 gee egter die volgende godsdienstige statistiek: Protestante $31,5 \%$, Rooms-Katolieke $27,6 \%$ Onafhanklike Kerke $2,9 \%$, Tradisionaliste $19 \%$ en Moslems $16,2 \%{ }^{8}$

Malawi, met sy besondere kenmerke en omstandighede, bied dus besondere uitdagings aan die Christelike kerke. Die Ned Geref Kerk wat 'n besondere rol gespeel het in verband met kerkplanting in die land, moet hom voortdurend afvra watter uitdagings Malawi in die toekoms aan hom gaan bied. Malawi is ' $n$ uitsondering in Afrika aangesien sy president, die Ngwazi (held), dr Hastings Kamuzu Banda openlik erkenning gee aan die rol en bydrae van die kerk en kerklike deelname aan die ontwikkeling van sy land verwelkom. By die honderdjarige feesvieringe van die Nkhoma Sinode het hy op Sondag 27 Augustus 1989 'n massa-byeenkoms op Nkhoma toegespreek en gesê: "This country came into being as a religious country. It was not born out of politics... If we are where we are now, it is because of Christianity brought into the country by early missionaries". Hoe 'n skrille kontras vorm dit nie met Nkwame Nkrumah se uitroep: "Soek eers die politieke koninkryk en alle ander dinge sal vir julle bygevoeg word"!

Ons wil dus vervolgens let op 'n aantal terreine waarop daar groot uitdagings vir die kerk wag en die vraag vra in watter opsigte die Ned Geref Kerk daar 'n bydrae in kan lewer. 
Met bykans $50 \%$ van sy bevolking wat nog of Tradisionaliste of Moslems is, wag daar nog 'n geweldige evangeliseringstaak op kerke in Malawi. Die Tradisionaliste woon verspreid in die dorpies tussen Christene en kan deur daaglikse getuienis van gelowiges bereik word. Die Moslems woon veral in die Meergebied waar Moskees in honderde dorpies die godsdienstige kern vorm. Hier het ons te doen met gespesialiseerde evangelisering waar die kerk in Malawi hulp en advies van buite behoort te verwelkom.

Naas die nie-Christene in Malawi self, is daar tans ook nog tussen 800,000 en een miljoen vlugtelinge vanuit Mosambiek op die grens tussen die twee lande. Die groot meerderheid van hulle is nie Christene nie en moet gekersten word. Hulle woon ook in haglike omstandighede en moet grootskaalse materiële hulp en geestelike vertroosting ontvang. Ook hier het kerke in Malawi hulp van buite nodig. Trouens, die kerke in Malawi behoort uitgedaag te word om wanneer die burgeroorlog in Mosambiek tot 'n einde kom, self op groot skaal sendelinge na die verskeurde land te stuur. Die kerk in Malawi ontbreek nog grootliks die visie vir georganiseerde sendinguitreiking na ongekerstende groepe rondom en binne die land. Die kerk moet in hierdie opsig gestimuleer word.

Die groot behoefte is nie meer om baie sendelinge na Malawi te stuur nie. Daar moet op kort termyn spesialiste aan die kerk daar geleen word om hulle te adviseer oor die beste maniere waarop die ongekerstende groepe bereik kan word. Verder kan hulp verleen word aan die skoling van lidmate en ampsdraers vir hulle getuienistaak. Op die terreine is daar nog ruimte vir 'n hele aantal meer geordendes om op versoek van die Nkhoma-sinode daar hulp te verleen.

Wat die vlugtelinge uit Mosambiek betref, behoort gemeentes uit SuidAfrika ernstig te oorweeg of hulle nie hulp in een of ander vorm kan aanbied nie. Dit is nie net 'n uitdaging vir die Kaapse Kerk nie maar vir die hele kerk. Vir hierdie akker sou ook nog kort-termyn sendelinge vir die kerk in Malawi aangebied kon word. Is daar nie gemeentes wat 'n werklose proponent vir ses maande of 'n jaar kan onderhou vir werk onder die vlugtelinge nie?

\section{Uitdagings op die terrein van kerkbou en bedieningsbehoeftes}

Die grootste krisis van die kerk in Malawi, is die gebrek aan intensiewe gemeentebou. Die kerke is oorvol en die arbeiders min. Die gevolg is oppervlakkigheid in die geloof en geestelike vervlakking. Gemeentes van tot 5000 lidmate word deur net een predikant bedien. Die 94 gemeentes van die Nkhoma Sinode met sy ongeveer 200,000 lidmate word deur 93 
predikante bedien. 'n Gemeente mag trouens nie afstig as daar nie minstens 2500 lidmate is nie aangesien hulle met minder lidmate nie 'n predikant kan onderhou nie. 'n Predikant kry ongeveer R250-00 per maand salaris en R100-00 per maand reiskoste. Hiermee kan hulle skaars 'n fiets bekostig want 'n fiets in Malawi kos R700-00. Meeste predikante het uitgestrekte gemeentes met tot 20 besoekpunte. Hulle vind dit egter moeilik om gereeld daar uit te kom.

Die oplossing vir die bedieningsprobleme kan in twee rigtings gesoek word:

Aan die een kant moet daar meer opgeleide predikante kom en aan die ander kant moet die ouderlinge uitgebou word tot 'n skare van tentmakerbedienaars. Daar moet ook aandag gegee word aan 'n beter benutting van die diakensamp.

Daar is nie 'n tekort aan mense wat hulle vir die bediening aanbied nie. In 1988 het 300 kandidate hulle vir teologiese opleiding aangebied. Die kerk het egter net fondse gehad om 5 toe te laat vir teologiese studie. Dit is 'n goeie beleid dat die Ned Geref Kerk nie die salarisse van leraars subsidieer nie. Dit lei tot ongesonde afhanklikheid. Daar behoort egter ernstig gepoog te word om beurse vir teologiese studente te bekom.

Daarby moet gemeentes opgevoed word tot groter offervaardigheid sodat meer predikante onderhou kan word.

Die Ned Geref Kerk kan ook steeds op kort termyn hulp verleen met die skoling van ouderlinge en diakens. Daar behoort aandag gegee te word aan die opgradering van ouderlinge tot tentmakerbedienaars. Indien hulle tot woordbediening en sakramentsbediening opgelei kan word, kan dit geweldig baie help om die bedieningsnood te verlig.

Die Ned Geref Kerk kan ook steeds hulp verleen met teologiese opleiding deur voorsiening van dosente op aanvraag en deur nagraadse studente wat kwalifiseer aan sy teologiese opleidingskole toe te laat.

\section{Die jeug as uitdaging}

Met 'n groeikoers van 3,3\% per jaar is 'n baie groot persentasie van die bevolking onder die ouderdom van 21 jaar. $48,2 \%$ van die bevolking is onder 15 jaar oud. Die jeug bied dus aan die kerke ' $n$ besondere uitdaging. Aangesien skoolgaan nie verpligtend is nie, is daar baie kinders wat op straat leef. Slegs $48 \%$ van die kinders tussen 6 en 13 jaar is op skool. Die kerk behoort te dink aan jeugklubs of ander aktiwiteite om hulle mee besig te hou. ${ }^{10}$ 
Die grootste uitdaging bly egter steeds die skoolgaande jeug. In 1985/86 was daar 942,539 kinders in primêre skole (tot ouderdom van ongeveer 14 jaar) en 25,177 in sekondére skole. In die jaar het die Universiteit van Malawi ongeveer 2000 studente gehad. Hoewel grootskaalse hulp van die International Development Association ontvang word vir oprigting van sekondêre skole, is fondse nog uiters beperk en kan slegs 'n beperkte getal kinders met sekondére onderwys voortgaan. ${ }^{11}$

Die Ned Geref Kerk het 'n trotse rekord van onderuys in Malawi. Van die begin af is die belangrikheid van die kind besef en is onderwysers aangestel. Spoedig het die stelsel van buiteposskole ontwikkel waar evangelisonderwysers in die week die kinders onderrig het en op Sondae die gemeente. In Suid-Afrika is buiteposondersteuners gewerf om die salarisse van die evangelisonderwysers te betaal. Teen 1918 was daar reeds 66700 leerlinge in 750 buiteposte waar 1400 onderwysers en evangelisonderwysers diens gedoen het. In 1975 is die stelsel van buiteposondersteuning vervang met 'n groep "Buitelandse Sendingondersteuners: Malawi". Daar is dus nog steeds geleentheid vir lidmate om by te dra via die Kaapse Sinodale Sendingkommissie vir die ondersteuning van onderwys in $\mathrm{Ma}$ lawi. ${ }^{12}$ As gevolg van beperkte fondse bestaan daar tans nog net 90 buiteposskole.

In 1902 reeds is met 'n Normaalskool begin vir opleiding van onderuysers en vanaf 1939 is daar 'n Opvoedkundige sekretaris wat onderwyssake behartig het. Talle blanke onderwysers het groot werk in Malawi gedoen veral in die sekondêre skole onder beheer van die kerk op Nkhoma en Kongwe.

Die Ned Geref Kerk kan dus steeds hulp verleen op die jeugterrein op die volgende maniere. Ondenwysers kan hulle aanbied vir onderwys in sekondére skole onder beheer van die kerk in Malawi. Van die staatsondersteunde skole is $\mathbf{2 4 7}$ primére skole onder toesig van die kerk asook die twee sekondére skole vir seuns op Nkhoma en Kongwe. Finansiële bydraes kan nog gegee word vir buiteposskole. Alle ondenwysersopleiding is egter nou deur die staat oorgeneem en gekonsolideer. Die geestelike toerusting van die kerk se lidmate in die staat se Normaalskole is egter van die grootste belang. Die Universiteit van Malawi bied 'n kursus in "religious studies" vir onderwysstudente aan. In 1989 het die Senaat dit goedgekeur dat 'n teologiese kursus op diploma-vlak aangebied word vir studente van verskillende kerke. (Daily Times, August 28, 1989:3). Dosente in teologie uit Suid-Afrika sou moontlik ook hier van diens kon wees. Predikante van die KMAP word by Zomba Teologiese Kollege opgelei. Ook daar word van tyd tot tyd nog buitelandse dosente aanvaar.

Die kerk kan ook jeugwerkers en -werksters op aanvraag voorsien om die 
inheemse kerk by te staan in die beplanning en organisasie van jeugwerk op alle vlakke. Daar is 90,000 kinders in kategeseskole en hulle het ook besondere aandag nodig. Daar is 'n groot behoefte aan die hersiening van Sondagskooisillabusse.

\section{Sosio-ekonomiese uitdagings}

Van die begin af het die Ned Geref Kerk in sy sendingaksie aandag gegee aan sosio-ekonomiese vraagstukke.

Besondere aandag is gegee aan die mediese terrein. In 1900 het die eerste dokter aangekom. Daarna het 'n ry van dokters en verpleegsters baanbrekerswerk op mediese gebied gedoen. Veral op die terrein van oogkunde het Suid-Afrikaanse dokters 'n onontbeerlike diens gelewer. Vier hospitale is deur die kerk ontwikkel waar jaarliks duisende binne- en buitepasiënte behandel word. Daar is nog steeds ruimte vir christen geneeshere uit Suid-Afrika om diens in die hospitale te lewer.

Die verspreiding van Vigs bied 'n geweldige uitdaging vir die kerk in Malawi. Die Nkhoma hospitaal alleen hanteer 30 tot 40 positiewe gevalle per maand. Van die bloed wat in hospitale getoets word, word tot meer as $20 \%$ besmet bevind. Daar word konserwatief geskat dat reeds 250,000 mense die virus het. Dit word dikwels by opgeleide beroepsmense aangetref. Talle kinders word met die virus gebore. Hierdie situasie skep 'n geweldige pastorale uitdaging vir die kerk. Vigspasiënte moet pastoraal begelei word, maar die kerk het ook 'n geweldige opvoedingstaak ter voorkoming van die siekte.

Die ekonomie in Malawi berus nog grootliks op die landbou. Landbouprodukte maak $90 \%$ van alle uitvoere uit. Die belangrikste uitvoerprodukte is tabak, tee, koffie, katoen en in die jongste tyd ook suiker. Die belangrikste stapelvoedsel vir binnelandse verbruik bly steeds mielies en $75 \%$ van alle landbougrond word daarmee beplant.

Die landbou word hoofsaaklik nog op tradisionele wyse beoefen. Op hierdie vlak is die maksimale produksievermoë feitlik bereik. Om die groot bevolkingsaanwas te kan akkommodeer sal meer moderne metodes toegepas moet word en veral oorgegaan moet word tot besproeiingsboerdery uit die Malawimeer wat 'n feitlik onuitputlike bron is. Landbouspesialiste uit Suid-Afrika wat boerdery omstandighede in Afrika ken, sou hierin 'n geweldige bydrae kon lewer.

Die vraag bly steeds of kerk en staat in Suid-Afrika nie moet saamwerk om dit vir jongmense met ' $n$ roeping moontlik te maak om gemeenskapsdiens en ontwikkelingswerk in ons buurlande te gaan doen nie. Dit behoort in die 
jare wat kom al hoe meer moontlik te wees.

Met sy geweldige bevolkingsaanwas sit Malawi eintiik op 'n tydbom. Min word nog gedoen aan verantwoordelike gesinsbeplanning. Die kerk word uitgedaag om veel meer te doen aan gemeenskapsontwikkeling en voorligting oor verantwoordelike ouerskap. Die Ned Geref Kerk met sy envaring in organisasies soos KAN en Mfesane kan spesialiste voorsien om hierin 'n bydrae te lewer.

Hierdie is maar enkele terreine op sosio-ekonomiese gebied wat uitdagings aan die kerk bied. Daar is egter talle meer waarop nie nou ingegaan kan word nie.

\section{Uitdagings op die politieke terrein}

Malawi het ook deur 'n periode van storm en drang na onafhanklikheid beweeg.

In 1891 is die gebied na onderhandelinge met Portugal tot 'n Britse protektoraat verklaar. In 1944 is die Nyassaland African Congress gestig en die beweging begin hom beywer vir onafhanklikheid. Dr Banda wat toe in Engeland as medikus gepraktiseer het, het toe al noue bande met die organisasie gehad. Op 6 Julie 1958 keer Banda na Malawi terug. Hy word spoedig verkies as president van die Congress en lei die teenstand teen die koloniale regering. Hy was veral gekant teen die Sentraal Afrikaanse Federasie wat in 1953 gevorm is en waarin Malawi in federale verband gedwing is met die Noord- en Suid-Rhodesië van destyds.

In 1959 kondig die koloniale regering 'n noodtoestand af en Banda word gearresteer en die Nyassaland African Congress verban. In dieselfde jaar nog word die Malawi Congress Party (MCP) gestig.

Die winde van verandering het nou begin waai in Afrika. Op 1 April 1960 word Banda deur Brittanje bevry. In die verkiesings wat in 1961 volg, het die MCP 'n groot meerderheid behaal. In 1963 word dr Banda die eerste minister. Hy doen die nodige aanvoorwerk en op 6 Julie 1964 word Malawi onafhanklik. In 1966 word die land 'n eenparty staat met 'n republikeinse konstitusie. Dr Banda word nou die eerste president en in 1971 word hy tot lewenslange president verkies met diktatoriale magte. ${ }^{14}$

Soos in meeste eenparty state het die politieke party en die president as hoof van die party feitlik onbeperkte mag. Daar word geen opposisie geduld nie. Opposisiegroepe is of in die gevangenis of moes uit die land vlug en opereer vandaar af teen die regering. Daar bestaan nie vryheid van spraak nie en ook nie vryheid van die pers nie. Die regering mag in geen opsig gekritiseer word nie. Mense leef in vrees dat hulle dalk iets verkeerd 
gesê het en verklap mag word. Die president self word met byna afgodiese eerbied vereer. Senior amptenare van die staat het ook geweldige magte. Ook hulle word nie gekritiseer nie omdat mense bang is dat hulle hulle werk kan verloor. Mense met die hoogste politieke gesag oorheers ook dikwels in die kerk omdat hulle nie teëgespreek mag word nie.

Dit is dus duidelik dat die kerk-staat verhouding in Malawi nie sonder probleme is nie. Die kerk het geen geleentheid om sy profetiese roeping teenoor die staat na te kom nie. Met 'n Christelike leier soos dr Banda skep dit tans nie onoorkomelike probleme nie. Die kerk is vry om sy werk te doen. Tog is die kerk nie vry om sosiale onreg te kritiseer nie. 'n Mens word koud om te dink wat binne so 'n stelsel sal gebeur as daar dalk eendag ' $n$ Idi Amin in Malawi aan bewind moet kom.

Die enigste oplossing vir hierdie politieke uitdaging sal wees dat kerk- en staatsleiers indringend oor hierdie knelpunte sal moet gesels. Om dit te kan doen, sal die kerk in Malawi goed opgeleide en bekwame leiers moet hê wat ook deur studie in die buiteland envaring van ander politieke stelsels opgedoen het.

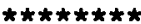

\section{DIE RCZ IN ZAMBIX EN OORBLYWENDE UITDAGINGS}

Ons het vir ds Pieter Theron, 'n doktorale student van ons Fakulteit en dosent aan die Justo Mwale Teologiese Kollege in Lusaka gevra om vir ons ' $n$ oorsig te gee van ' $n$ paar belangrike uitdagings vir die $R C Z$ in Zambië. Wat hier volg, is die verslag wat ons van hom ontvang het:

Die Reformed Church in Zambia vier oor 9 jaar, in 1999, sy 100-jarige bestaan. In 1899 het die eerste sendelinge vanuit Suid-Afrika die werk hier begin. Vandag kan met groot trots en dankbaarheid gesé word dat hierdie kerk sterk staan en groei. Dit is ook tot 'n groot mate 'n selfstandige kerk, veral as dit vergelyk word met ander kerke in Zambië. Die vraag kan gevra word of die huidige groei van die kerk toegeskrył kan word aan die natuurlike groei van die lidmate as gevolg van geboortes, en of dit groei as gevolg van nuwe bekeerlinge, of dalk beide. Dit is ' $n$ saak wat 'n ondersoek waardig is.

Wat is die oorblywende uitdagings vir hierdie kerk in Zambië? In hierdie artikel wil ons kortliks daaraan aandag gee, en dan veral vanuit die perspektief van die missionêre taak van die kerk gesien.

\section{Sending}

Dadelik moet ons versigtig wees wanneer ons die term sending in die 
Afrika konteks en veral in die konteks van Zambië gebruik. Daar bestaan soveel slegte konnotasies en herinneringe rondom hierdie term vir die mense hier, dat die term as't ware vermy word. Dit het ook in 'n groot mate daartoe gelei dat daar nie veel van die missionêre taak van die kerk, as 'n toegespitse bediening, tereg gekom het nie. Wei het die kerk in haar normale bediening 'n missionêre dimensie gehad, en is ongelowiges bereik. Hier is dit veral die evangeliste wat 'n baie groot taak verrig. Maar 'n definitiewe, toegespitste missionêre uitreik bestaan nie. Die evangelisasie wat wel plaasvind is meer terloops as beplan - die werk van die evangeliste uitgesonder. Dit is die eerste groot uitdaging vir die kerk - om weer opnuut te besin oor haar missionêre taak in 'n nuwe konteks en in 'n nuwe tydvak. Die ou "sending"-fase is verby. Ons kan nie meer terugkyk en vashaak in die verlede nie. Ons moet vorentoe en ons moet aangaan met ons missionêre taak en roeping. Al is dit in nuwe terme, met 'n nuwe verstaan en nuwe metodes. Dit is die nuwe en seker die grootste uitdaging. Om ons missionêre taak in die nuwe konteks en tyd te identifiseer, te definieer en te implementeer.

Wanneer ons van sending in Zambië praat moet ons verder ook versigtig wees om nie in terme van sending in heidense gebiede te dink nie. Zambië kan vandag beskryf word as 'n Christelike land - $77 \%$ van die bevolking is Christene. ${ }^{15}$ Omtrent die hele Zambië is al bereik deur of het al kontak gehad met die evangelie in een of ander vorm, hetsy die kerk self, sendingstasies, sendelinge, evangeliste, ander Christene, of deur die media. Natuurlik geld dieselfde probleem wat ons in enige ander land kry ook hier, naamlik dat nie alle sogenaamde Christene, Christene is nie. Ons sal hier ook 'n duidelike onderskeid moet tref tussen nominale Christene en ware gelowiges wat hulle geloof uitleef.

Die tweede uitdaging is dié van sekularisme, veral in die stedelike gebiede en in die industrieë soos byvoorbeeld die myndorpe van die Koperstreek. Baie mense wil nie godsdienstig wees nie of wend hulle net tot die godsdiens in tye van nood en dan gewoonlik tot die tradisionele godsdiens of ' $n$ mengsel van die tradisionele en die Christelike. Baie mense is gedoop of het selfs Sondagskool deurgegaan, maar het daarna nog nooit weer enige kontak met die kerk gehad nie. Dus het ons hier ook dieselfde probleem van sekularisme en kerkvervreemding as in Suid-Afrika. Industriële en stedelike sending moet veral hier aandag kry. Veral stedelike sending want verstedeliking geskied hier teen 'n geweldige tempo en daarmee saam al die gepaardgaande probleme soos werkloosheid, drankmisbruik en immoraliteit.

'n Derde baie groot uitdaging is die jeug. Jeugwerk geniet baie aandag en is besig om te groei as gevolg van die Jeugsentrum van die RCZ en die 
ywer waarmee mense soos ds Deon Loots en sy vrou werk, tesame met die Zambiese werkers soos ds R Daka. Baie van die jongmense stel net nie belang in die kerk nie. Die kerk is vir die oumense sê hulle. Dié wat wel belangstel en aktief in die kerk is, voer 'n moeilike en opdraande stryd omdat die gemeentes en kerkrade nie altyd vir hulle voorsiening maak nie. Dit lei tot konflik tussen die jeug en die kerkraad wat soms drastiese afmetings aanneem soos skorsing van jongmense uit die gemeente. Die jeug soek hulp, leiding en aktiewe deelname aan die gémeentelike lewe, maar vind dit nie. Drankmisbruik is ' $n$ groot probleem asook immoraliteit. Die getalle van jong meisies wat die skool moet verlaat weens swangerskappe is ontsettend hoog. Hier het die kerk 'n baie groot taak om te verrig in terme van hulp, leiding en opvoeding. In die tradisionele kultuur het die hofmakery en verhoudings tussen die geslagte volgens streng reëls geskied. In die stede is hulle buite hierdie tradisionele kultuur en die beheer en riglyne wat dit gebied het. Nou weet hulle nie altyd mooi hoe om die situasie en die probleme te hanteer nie.

Omdat daar nie in die erediens en in die gemeentebediening genoegsaam aandag aan kinders gegee word nie, is die gevaar van verwydering van die kerk groot.

Die meerderheid van die RCZ se lidmate bestaan uit vrouens, en die kerk word as't ware deur hulle gedra. Baie van die mans is nie Christene nie en dit kan lei tot spanning in die families. Die kerk sal aandag moet gee aan hoe om die mans met die evangelie te bereik en hulle suksesvol pastoraal te bedien.

\section{Die Platteland}

Baie van bogenoemde probleme en uitdagings geld ook vir die platteland, maar die platteland het ook sy eie unieke karakter en probleme. Die plattelandse gemeentes beslaan geweldige groot areas en die predikant het nie vervoer nie. Dit het tot gevolg dat gemeentebediening sowel as evangeliseringswerk nie doeltreffend uitgevoer kan word nie.

Die probleem word verder bemoeilik deur denominasionalisme wat veral in die platteland sterk na vore kom. In een klein dorpie van vyf tot agt huisgesinne kan tot vier verskillende denominasies voorkom. Selfs tot in een huisgesin kan die lede aan verskillende kerke behoort. Buiten die spanninge wat so ontstaan, lei dit ook nog tot oor en weer beskuldigings van proselitisme en oortreding van terrein tussen die kerke. Dit gebeur selfs wanneer die persoon wat geëvangeliseer word aan geen kerk behoort nie. Kerke wat finansiëel sterk staan (omdat hulle geld van oorsee kry), trek ook somtyds meer mense omdat hulle materieel meer bied as die ander. Dit lei in baie gevalle tot oppervlakkige bekerings. 
Dit is ook veral in die plattelandse gemeentes waar die tradisionele godsdienste nog baie sterk funksioneer. Tog kom dit in die stede ook voor al is dit in 'n gewysigde vorm. In hierdie opsig is dit veral magie wat 'n baie sterk rol speel en selfs Christene wend hulle hiertoe. Die kerk sal hierdie probleem moet aanspreek en dit nie net afmaak as bygeloof nie. Duiwelbesetenheid kom baie voor en die kerk moet hier definitiewe riglyne gee. Ook die tradisionele genesing funksioneer nog sterk en die kerk sal dit ook moet ondersoek en Christelike riglyne gee asook bepaal of alles wat tradisioneel is, werklik verkeerd en onchristelik is.

\section{Missionêre diakonaat}

Die missionêre taak van die kerk bestaan nie net uit die verkondiging van die evangelie aan ongelowiges nie, maar ook uit haar uitreik na die wêreld. Hier moet die RCZ ernstig aandag gee aan die swak ekonomiese toestand in die land wat nou baie ernstige afmetings begin aanneem. Dit lei tot baie ernstige probleme, nie net praktiese nie maar ook etiese, soos die swart mark, smokkelary, korrupsie, wilddiefstal en die toename in die misdaadsyfer. Die kerk moet haar profetiese taak ook hier vervul en waar nodig die regering aanspreek oor probleme en wanpraktyke. Ook met betrekking tot ontwikkeling en ekologiese probleme moet die kerk haar stem laat hoor, maar nie net laat hoor nie, maar ook daadwerklik iets doen.

Ten slotte, die RCZ het baie en groot uitdagings voor haar om die evangelie aan ongelowiges te verkondig in woord en daad. Maar hand aan hand hiermee het die kerk ook die taak en uitdaging om haar lidmate bewus te maak van hulle missionêre roeping, en om huile op te lei en toe te rus vir hierdie taak. Gelukkig begin die kerk daarmee te worstel.

Tweedens, is finansies 'n groot probleem, maar as die mense se gesindheid reg is en hulle is opgelei om die taak uit te voer, kan baie gedoen word ten spyte van die tekort aan finansies.

\section{NOTAS}

1. D Crafford, Aan God die Dank, Deel 1, Pretoria 1982, $83 v$.

2. J D Thom, "Wes Kaapse Sending in 'n Neutedop", Die Sendingblad, Jaargang 25, $\mathrm{Nr}$ 6/7 (1989), 16-17.

3. Thom, Die Sendingblad, Ibid.

4. J M Cronje, Aan God die Dank, Deel 2, Pretoria 1981, $144 v$.

5. Thom, Die Sendingblad, Ibid. Vergl. Cronjé. a.w., 194v. 
6. A MacGregor Hutcheson, "Malawi: Physical and Social Geography", Africa South of the Sahara 1989, London, 651.

7. J H Kane, A Global View of Christian Missions, Michigan 1977, 407.

8. Bulletin United Bible Society, No 150/151 (1988) by Malawi.

9. Daily Times (of Malawi), Augustus 28, 1989,1.

10. Louise Koch, "Eeufeesjaar van die Malawi-Sending", Die Sendingblad, Jaarg 25, No 2 (1989) 6-8.

11. Africa South of the Sahara 1989, by Malawi, 671.

12. Cronjé, a.w., 45v.

13. Koch, a.w., 6.

14. C M Pauw, Mission and Church in Malawi, Stellenbosch 1980, $11 \mathrm{v}$.

15. P Johnstone, Operation World, Bromley 1985, 458. 